\title{
Analisis Pengaruh Sanitasi dan Akses Air Bersih Terhadap Indeks Pembangunan Manusia di Jawa Tengah
}

\author{
Fita Purwaningsih*, Suharno, Abdul Aziz Ahmad \\ Fakultas Ekonomi dan Bisnis, Universitas Jendral Soedirman, Purwokerto \\ "Correspondence email: fitapurwaningsih16@gmail.com
}

\begin{abstract}
Abstrak. Indeks Pembangunan Manusia (IPM) Provinsi Jawa Tengah tahun 2015-2018 terendah jika dibandingkan dengan provinsi lainnya di Pulau Jawa. Penelitian ini bertujuan menganalisis pengaruh sanitasi, akses air bersih, kemiskinan, jumlah penduduk, dan pertumbuhan ekonomi terhadap Indeks Pembangunan Manusia di Provinsi Jawa Tengah tahun 2015-2018. Metode yang digunakan dalam penelitian adalah regresi linier berganda dengan pendekatan data panel. Hasil penelitian menunjukkan bahwa sanitasi, jumlah penduduk, dan pertumbuhan ekonomi berpengaruh positif dan signifikan terhadap Indeks Pembangunan Manusia di Provinsi Jawa Tengah. Kemiskian berpengaruh negatif dan signifikan terhadap Indeks Pembangunan Manusia di Provinsi Jawa Tengah Sementara itu, akses air bersih tidak berpengaruh terhadap Indeks Pembangunan Manusia di Provinsi Jawa Tengah. Temuan ini mengimplikasikan perlunya pembangunan sanitasi yang merata bagi penduduk di Provinsi Jawa Tengah. Selain itu perlunya pemerintah dalam meningkatkan pertumbuhan ekonomi, dan mengurangi jumlah penduduk miskin.
\end{abstract}

Kata Kunci: Indeks Pembangunan Manusia; Sanitasi; Infrastruktur Air

Abstract. Human Development Index (HDI) of Central Java Province in 2015-2018 is the lowest compared to other provinces in Java Island. This study aims to analyze the effect of sanitation, water access, poverty, population, and economic growth on Human Development Index in Central Java Province at 2015-2018. The method used in this research is multiple linear regression with a panel data approach. The results show that sanitation, population, and economic growth have a positive and significant effect on the Human Development Index in Central Java Province. Poverty have a negative and significant effect on the Human Development Index in Central Java Province. Meanwhile, access to water has no effect on the Human Development Index in Central Java Province. This finding implies the need for equitable sanitation development for the population in Central Java Province. In addition, the government needs to increase economic growth and reduce the number of poor people.

Keywords: Human Development Index; Sanitation; Water Infrastructure

\section{PENDAHULUAN}

Paradigma baru mengenai pembangunan ekonomi sejatinya tidak hanya terkhususkan pada pembangunan fisik namun juga mementingkan pembangunan manusia dalam proses pembangunan ekonomi (Hilal dan Sukamdi, 2015). Alisjahbana dan Murniningtyas (2018) mengatakan pembangunan yang berkesinambungan merupakan syarat mutlak kelangsungan hidup suatu negara yang bertujuan terciptanya lingkungan yang kondusif dan dapat menunjang kualitas hidup masyarakat. Sebagai konsensus Sustainable Development Goals (SDGs), target-target yang harus tercapai diantaranya adalah memacu masyarakat yang berkualitas dengan adanya pembangunan kesehatan, pendidikan dan perbaikan daya beli masyarakat. Pembangunan sumber daya manusia mencakup aspek peningkatan kapasitas dasar yang sekaligus sebagai nilai pokok keberhasilan ekonomi yaitu kecukupan, jati diri, serta kebebasan (Todaro, 2003). Kecukupan dalam hal ini di jelaskan sebagai kamampuan untuk terpenuhnya kebutuhan sandang, pangan, papan, kesehatan, keamanan, dan pendidikan.

Indeks Pembangunan Manusia (IPM) merupakan salah satu indikator untuk mengukur tingkat pembangunan pada aspek sosio-ekonomi yang banyak digunakan baik oleh negara berkembang maupun negara maju (Rizki \& Saleh, 2007). Tiga akses penting yang digunakan untuk perhitungan IPM yaitu (1) kesehatan yang dilihat dari angka harapan hidup; (2) pendidikan yang dicerminkan dari angka melek huruf dan rata-rata melek sekolah; dan (3) pendapatan masyarakat dengan melihat daya beli masyarakat. Gambar 1 menunjukkan tingkat IPM provinsi-provinsi yang ada Pulau Jawa. Dari gambar tersebut dapat dilihat bahwa pada tiap tahunnya Provinsi DKI Jakarta memiliki angka IPM yang jauh lebih tinggi dari provinsi-provinsi lainnya. Jawa Tengah menduduki peringkat kelima dengan angka IPM paling tinggi di Pulau Jawa. Provinsi Jawa tengah memiliki Indeks Pembangunan Manusia (IPM) terendah jika dibandingkan dengan provinsi lainnya di Pulau Jawa, dengan demikian perlu analisis lebih lanjut mengani faktor-faktor yang memengaruhi Indeks Pembngunan Manusia di Provinsi Jawa Tengah. 


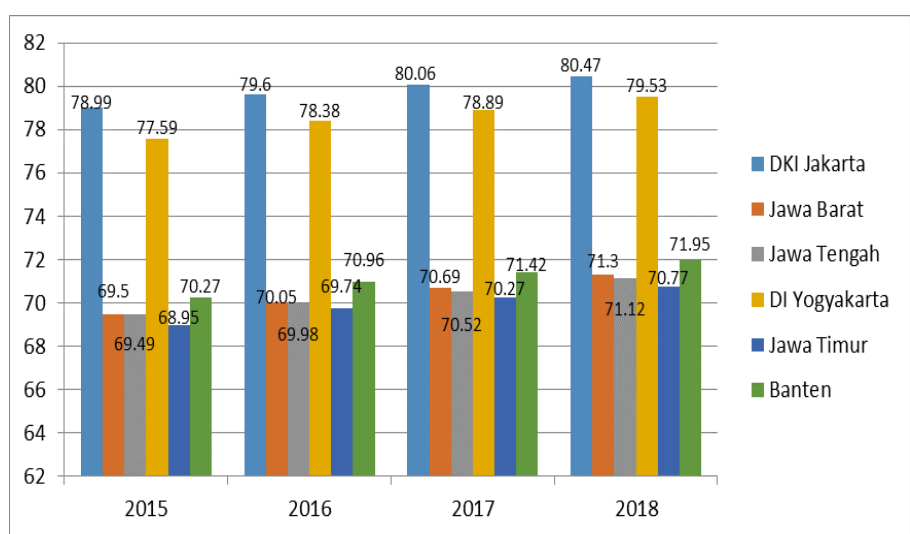

Gambar 1. Tingkat Indeks Pembangunan Manusia Menurut Provinsi di Pulau Jawa Tahun 2015-2018

Sumber: BPS, 2018

Salah satu unsur yang menyusun Indeks Pembangunan Manusia adalah kesehatan. Kesehatan yang baik didukung dengan fasilitas kesehatan dan sanitasi yang baik pula. Selain itu pemerintah juga cukup serius dalam mengatasi permasalahan sanitasi dan air bersih di Indonesia yang telah dituangkan di Rencana Kerja Pemerintah (RKP), Rencana Pembangunan Jangka Menengah Nasional (RPJMN), hingga Sustainable Development Goals (SDGs). Sanitasi dan air bersih adalah kebutuhan dasar individu. Permasalahan sanitasi dan air bersih menjadi menjadi permasalahan umum tidak hanya di Indonesia namun permasalahan di dunia. Ketersediaan air bersih dan sanitasi merupakan prioritas ke enam yang harus dikerjakan dengan serius agar tujuan dari SDGs tercapai.

Menurut Soeranto (2004) dan Kusharjanto (2011), secara empiris sanitasi yang dibangun dengan kualitas yang baik mampu menaikkan tingkat kesehatan masyarakat dimana kesehatan merupakan salah satu indikator pembangun IPM. Artinya bahwa semakin baik pembangunan sanitasi serta pengadaan air bersih dalam penelitian ini diukur dari jumlah rumah tangga yang menggunakan sanitasi dan air bersih, maka peluang masyarakat untuk sehat menjadi lebih tinggi sehingga akan IPM akan meningkat. Hal ini didukung dengan penelitian Sapkota (2014), Mungkasa (2004), Samudro (2004), dan Melliana \& Zain (2013) yang menyatakan bahwa pembangunan infrastruktur salah satunya adalah sanitasi dan drainase mampu meningkatkan IPM atau Human Development Index (HDI).

Jawa Tengah termasuk salah satu provinsi dengan pertumbuhan penduduk yang tinggi. Menurut Mirza (2012) pertumbuhan penduduk dapat menjadi sumber potensi untuk diberdayakan. Hal ini juga diperjelas oleh Todaro dan Smith (2006) bahwa penduduk berperan sebagai pasar yang potensial dalam proses pembangunan. Jumlah penduduk yang semakin meningkat artinya ketersediaan tenaga kerja akan semakin banyak, sehingga apabila tenaga kerja dapat terserap dengan baik maka akan memutar roda perekonomian yang pada gilirannya akan meningkatkan kesejahteraan masyarakat itu sendiri. Kesejahteraan tersebut salah satunya dapat diukur dengan kemampuan daya beli dimana hal ini termasuk dalam perhitungan IPM.

Angka kemiskinan salah satunya dapat dicerminkan dari angka IPM pada suatu wilayah (Tamboto \& Manongko, 2019). Menurut Sharp dalam Kuncoro (2006) kemiskinan didefinisikan sebagai rendahnya kualitas sumber daya manusia baik deri segi pendidikan maupun kesehatan. Hal ini dapat menurunkan produktivitas tenaga kerja yang dalam jangka panjang berakibat pada menurunnya penghasilan dengan konsekuensi terburuk yaitu pemecatan tenaga kerja, kemudian seseorang tersebut tidak mampu memenuhi seluruh kebutuhan pokoknya atas akibat dari menurunnya pendapatan (Umiyati et al. 2017). Oleh karena itu, semakin tinggi angka kemiskinan maka akan menurunkan kualitas sumber daya manusia yang dicerminkan melalui IPM.

Selain itu, IPM juga dipengaruhi oleh pertumbuhan ekonomi. Menurut Chalid dan Yusuf (2014) pertumbuhan ekonomi merupakan cerminan dari proses aktivitas perekonomian yang dapat menambah pendapatan masyarakat di suatu tahun tertentu. Dengan adanya peningkatan pendapatan maka daya beli masyarakat akan meningkat dimana salah satu aspek yang menyusun IPM adalah pendapatan yang diukur dari daya beli masyarakat (Muliza, et al., 2017). Artinya bahwa apabila pertumbuhan ekonomi meningkat maka angka IPM juga akan mengalami peningkatan.

Dengan demikian tujuan dari penelitian ini adalah mengalaisis pengaruh kemiskinan, rumah tangga yang memiliki akses sanitasi, rumah tangga yang mengakses air bersih, jumlah penduduk, dan pertumbuhan ekonomi terhadap indeks pembangunan manusia di Provinsi Jawa Tengah tahun 2015-2018.

\section{METODE}

Penelitian ini mengunakan pendektan kuantitatif. penelitian ini dilakukan di Provinsi Jawa Tengah dengan menggunakan menggunakan data panel, yaitu gabungan dari data cross section dan time series. Data cross section dalam penelitian ini adalah 35 kabupaten kota dan data time series adalah tahun 2015-2018 di Provinsi Jawa Tengah. Variabel dependen dalam penelitrian ini adalah Indeks Pembangunan Mansusia yang diukur dengan satuan indeks. Sementara itu variabel independen dalam penelitian ini adalah sanitasi yang diukur dengan satuan persentase, akses air bersih yang diukur dengan satuan persentase, kemiskinan yang diukur dengan satuan persentase, dan pertumbuhan ekonomi yang diukur dengan satuan persentase. Data diperoleh dari Badan Pusat Statistik Provinsi Jawa Tengah, serta lembaga terkait lainnya.

Teknik analisis menggunakan regresi linier berganda dengan pendekatan data penel. Data panel merupakan penggabungan antara data cross section dan 
data time series dan. Data cross section adalah data yang dikumpulkan dari waktu ke waktu terhadap banyak individu, sedangkan time series data yang dikumpulkan dari waktu ke waktu terhadap suatu individu (Gujarati dan Porter, 2013). Berikut ini adalah persamaan penelitian yang diguanakan dalam penelitian :

$\mathrm{IPM}_{\mathrm{it}}=\beta_{0}+\beta_{1} \mathrm{SNTS}_{\mathrm{it}}+\beta_{2} \mathrm{AAB}_{\mathrm{it}}+\beta_{3} \mathrm{KMK}_{\mathrm{it}}+\beta_{4} \mathrm{JP}_{\mathrm{it}} \beta_{5} \mathrm{PE}_{\mathrm{it}}+\mathrm{e}_{\mathrm{it}}$

Dimana:

$\begin{array}{ll}\text { IPM } & =\text { Indeks Pembangunan Manusia } \\ \mathrm{B}_{0,1,2,3,4,5,6} & =\text { Koefisien Regresi } \\ \mathrm{SNTS} & =\text { Sanitasi } \\ \mathrm{ABB} & =\text { Akses Air Bersih } \\ \mathrm{KMK} & =\text { Kemiskinan } \\ \mathrm{JP} & =\text { Jumlah Penduduk } \\ \mathrm{PE} & =\text { Pertumbuhan Ekonomi } \\ e & =\text { Standard error } \\ i & =\text { Time series } \\ t & =\text { cross section }\end{array}$

Dalam penelitian yang menggunakan pendekatan data penel terdapat tiga model yang dapat digunakan yaitu model common effect, fixed effect dan random effect. Dari ketiga model terbut harus dipilih salah satu dengan mengunkan uji Chow, Hausman, dan Lagrange Multiplier (Gujarati dan Porter, 2013). Selain itu, model regresi yang baik haris memenuhi standart Best, Linear, Unbiased Estimator. Standar tersebut hasil regresi harus lolos uji asumsi klasik yang terdiri dari uji normalitas, multikolineritas, heteroskedastisitas, dan autokorelasi (Gujarati dan Porter, 2013).

\section{HASIL DAN PEMBAHASAN}

Dalam penelitian ini model regresi yang digunakan adalah model regresi data panel. Berdasarkan uji pemilihan model meliputi uji Chow dan Uji Hausman menunjukkan bahwa model fixed effect adalah yang dipilih. Berikut ini ringkasan uji pemelihian model dalam penelitian ini.

Tabel 1. Ringkasan Uji Kecocokan model

\begin{tabular}{ccccc}
\hline \multirow{2}{*}{ No } & \multicolumn{2}{c}{ Uji Chow } & \multicolumn{2}{c}{ Uji Hausman } \\
\cline { 2 - 4 } & Effects Test & P-Value & Test Summary & $P$-Value \\
\hline 1 & Cross-section Chi-square & 0,0000 & Cross-section random & 0,0000 \\
\hline
\end{tabular}

Pada fixed effect model dalam penelitian ini sudah dinyatakan lolos uji asumsi klasik yang terdiri dari uji autokorelasi, uji multikolinearitas, uji heteroskedastisitas, dan uji nomalitas. Dengan demikian hasil penelitian ini dapat digunakan dan dilakukan pembahasan lebih lanjut. Berikut ini Tabel 2 yang menunjukkan ringkasan regresi fixed effect model yang digunakan dalam penelitian ini.

Tabel 2.Ringkasan Regresi Fixed Effect Model.

\begin{tabular}{|c|c|c|c|c|}
\hline Variabel & Koefisien & $\mathrm{T}$-Statistik & T-Tabel & P-Value \\
\hline Sanitasi & 0,0055 & 2,9277 & 1,9993 & 0,0004 \\
\hline Akses Air Bersih & 0,0026 & 0,4402 & 1,9993 & 0,4607 \\
\hline Kemiskinan & $-0,1936$ & $-5,3829$ & 1,9993 & 0,0000 \\
\hline Jumlah Penduduk & 2,5481 & 4,5696 & 1,9993 & 0,0000 \\
\hline Pertumbuhan Ekonomi & 5,3619 & 7,8589 & 1,9993 & 0,0000 \\
\hline$R$-Squared & 0,9975 & & & \\
\hline Adjusted R-Squared & 0,9965 & & & \\
\hline Prob F-Statistik & 0,0000 & & & \\
\hline
\end{tabular}

Sumber: data diolah, 2020

Variabel sanitasi memiliki koefisien regresi sebesar 0,0055 dengan nilai probabilitas sebesar 0,0004. Hal tersebut menunjukkan bahwa sanitasi berpengaruh positif dan signifikan terhadap Indeks Pembangunan Manusia (IPM) di Provinsi Jawa Tengah tahun 20152018. Hal ini membuktikan bahwa semakin baik pembangunan sanitasi dalam penelitian ini diukur dari jumlah rumah tangga yang menggunakan sanitasi, maka peluang masyarakat untuk sehat menjadi lebih tinggi, sehingga akan IPM akan meningkat. Hal ini didukung dengan penelitian Rizki \& Saleh (2007), Sapkota (2014), Mungkasa (2004), Samudro (2004), dan Melliana \& Zain (2013) yang menyatakan bahwa pembangunan infrastruktur salah satunya adalah sanitasi dan drainase mampu meningkatkan Indeks Pembangunan Manusia atau Human Development Index (HDI).

Kajian UNICEF Indonesia juga menemukan pentingnya sanitasi yang baik untuk kesehatan masyarakat. Sanitasi dan perilaku kebersihan yang buruk serta air minum yang tidak aman berkontribusi terhadap 88 persen kematian anak akibat diare di seluruh dunia. Bagi anak-anak yang bertahan hidup, seringnya menderita diare berkontribusi terhadap masalah gizi, sehingga menghambat anak untuk berkembang dengan baik. Kondi tersebut dapat berdampak langsung terhadap rendahnya Indeks Pembangunan Manusia. Kajian World Bank juga memperlihatkan manfaat terhadap kesehatan dan nutrisi hanya diraih optimal, 
apabila diikuti dengan Stop Buang Air Besar Sembarangan (BABS) atau Open Defecation Free (ODF) dan cakupan akses sanitasi yang layak di lebih dari 60 persen penduduk suatu daerah.

Variabel akses air bersih memiliki koefisien regresi sebesar 0,0026 dengan nilai probabilitas sebesar 0,4607 . Hal tersebut menunjukkan bahwa askses air bersih tidak berpengaruh terhadap Indeks Pembangunan Manusia (IPM) di Provinsi Jawa Tengah tahun 20152018. Hasil penelitian ini tidak sejalan dengan Melliana \& Zain (2013) yang menyatakan bahwa pembangunan infrastruktur salah satunya adalah sanitasi dan drainase mampu meningkatkan Human Development Index (HDI). Hal tersebut dikarenakan dengan adanya akses air bersih yang baik, tanpa adanya kesadaran masyarakat terhadap pola hidup sehat maka akses air bersih tidak dapat berpengaruh signifikan terhadap Indeks Pembangunana Manusia. Selain itu, juga perlunya kesadaran masyarakat dalam pemenuhan gizi yang cukup terhadap anggota keluarga.

Variabel kemiskinan memiliki koefisien regresi sebesar -0,1936 dengan probabilitas sebesar 0,0000. Hal tersebut menunjukkan bahwa kemiskinan berpengaruh negatif dan signifikan terhadap Indeks Pembangunan Manusia di Provinsi Jawa Tengah tahun 2015-2018. Menurut Sharp dalam Kuncoro (2006) kemiskinan didefinisikan sebagai rendahnya kualitas sumber daya manusia baik deri segi pendidikan maupun kesehatan. Hal ini dapat menurunkan produktivitas tenaga kerja yang dalam jangka panjang berakibat pada menurunnya penghasilan dengan konsekuensi terburuk yaitu pemecatan tenaga kerja, kemudian seseorang tersebut tidak mampu memenuhi seluruh kebutuhan pokoknya atas akibat dari menurunnya pendapatan (Umiyati et al. (2017). Hasil ini didukung dengan penelitian sebelumnya oleh Ginting (2008) dan Mirza (2012). Semakin tingginya persentase penduduk miskin di suatu daerah akan berdampak pada Indeks Pembangunan Manusianya. Hal ini dikarenakan semakin rendahnya pendapatan, sehingga penduduk tidak dapat mengakses fasilitas pendidikan, kesehatan dan konsumsi kebutuhan pokok yang layak.

Variabel jumlah penduduk memiliki koefisien regresi sebesar 2,5481 dan nilai probabilitasnya sebesar 0,0000. Hal tersebut menunjukkan bahwa jumlah penduduk berpengaruh positif dan signifikan terhadap terhadap Indeks Pembangunan Manusia di Provinsi Jawa Tengah tahun 2015-2018. Menurut Mirza (2012) pertumbuhan penduduk dapat menjadi sumber potensi untuk diberdayakan. Hal ini juga diperjelas oleh Todaro dan Smith (2006) bahwa penduduk berperan sebagai pasar yang potensial dalam proses pembangunan. Semakin bertambahnya jumlah penduduk, dan didukung dengan fasilitas pendidikan dan kesehatan maka pertumbuhan penduduk dapat meningkatkan Indeks Pembangunan Manusia
Variable pertumbuahan ekonomi memiliki koefisien regresi sebesar 5,3619 dan probabiltas sebesar 0,0000 . Hal tersebut menunjukkan bahwa pertumbuhan ekonomi berpengaruh positif dan signifikan terhadap terhadap terhadap Indeks Pembangunan Manusia di Provinsi Jawa Tengah tahun 2015-2018. Menurut Chalid dan Yusuf (2014) pertumbuhan ekonomi merupakan cerminan dari proses aktivitas perekonomian yang dapat menambah pendapatan masyarakat di suatu tahun tertentu. Dengan adanya peningkatan pendapatan maka daya beli masyarakat akan meningkat dimana salah satu aspek yang menyusun Indeks Pembanguna Mmanusia adalah pendapatan yang diukur dari daya beli masyarakat (Muliza, et al. 2017). Hasil ini sesuai dengan penelitian dari Muliza et al., (2017), Chalid dan Yusuf (2014).

\section{SIMPULAN}

Hasil penelitian menunjukkan bahwa variabel sanitasi, jumlah penduduk, dan pertumbuhan ekonomi berpengaruh positif dan signifikan terhadap Indeks Pembangunan Manusia di Provinsi Jawa Tengah tahun 2015-2018. Kemiskian berpengaruh negatif dan signifikan terhadap Indeks Pembangunan Manusia di Provinsi Jawa Tengah tahun 2015-2018. Sementara itu, akses air bersih tidak berpengaruh terhadap Indeks Pembangunan Manusia di Provinsi Jawa Tengah tahun 2015-2018. Hal tersebut mengimplikasikan bahwa perlunya pembangunan sanitasi yang merata bagi penduduk di Provinsi Jawa Tengah. Selain itu perlunya pemerintah dalam meningkatkan pertumbuhan ekonomi, dan mengurangi jumlah penduduk miskin guna meningkatkan Indeks Pembangunan Manusia di Provisni Jawa Tengah.

\section{DAFTAR PUSTAKA}

Alisjahbana, A. S. \& Murniningtyas, E. (2018). Tujuan Pembangunan Berkelanjutan di Indonesia: Konsep Target dan Strategi Implementasi. Bandung: UNPAD Press

Badan Pusat Statistik (BPS). (2019). Indeks Pembangunan Manusia 2015 - 2019. BPS, Jawa Tengah.

Badan Pusat Statistik (BPS). (2019). Presentase Kemiskinan Jawa Tengah 2015 - 2019. BPS, Jawa Tengah.

Badan Pusat Statistik (BPS). (2019). PDRB Harga Konstan per Kabupten 2015 - 2019. BPS, Jawa Tengah.

Badan Pusat Statistik (BPS). (2019). Jumlah Penduduk per Kabupaten 2015 - 2019. BPS, Jawa Tengah.

Badan Pusat Statistik (BPS). (2019). Persentase Rumah Tangga Yang Memiliki Akses Sanitase 2015 2019. BPS, Jawa Tengah.

Badan Pusat Statistik (BPS). (2019). Persentase Penggunaan Air Bersih 2015 - 2019. BPS, Jawa Tengah. 
Fita Purwaningsih, Suharno dan Abdul Aziz Ahmad, Analisis Pengaruh Sanitasi dan Akses Air Bersih Terhadap Indeks

Chalid, N. \& Yusuf, Y. (2014). Pengaruh Tingkat Kemiskinan, Tingkat Pengangguran, Upah Minimum Kabupaten/Kota dan Laju Pertumbuhan Ekonomi Terhadap Indeks Pembangunan Manusia di Provinsi Riau. Jurnal Ekonomi, 22(2): 1-12. http://dx.doi.org/10.31258/je.22.2.p.1-12

Dewi, N. (2017). Pengaruh Kemiskinan dan Pertimbuhan Ekonomi terhadap Indeks Pembangunan Manusia di Provinsi Riau. JOM Fekon 4(1): 870-882.

Gujarati, D, N,. \& Porter, D. C. (2013). Basic Econometrica. Mc Grwa Hill, Inc, New York.

Hilal, G. M., \& Sukamdi, S. (2015). Pengaruh Pembangunan Manusia terhadap Pembangunan Ekonomi di Negara Berkembang. Jurnal Bumi Indonesia, 4(4): 1-10

Kuncoro, M. (2006). Ekonomi Pembangunan. Jakarta: Salemba Empat.

Kusharjanto, H. \& Kim, D. (2011). Infrastructure and Human Development: The Case of Java, Indonesia. Journal of The Asia Pacific Economy, 16(1):

111-124. https://doi.org/10.1080/13547860.2011.539407

Melliana, A., \& Zain, I. (2013). Analisis Statistika Faktor yang Mempengaruhi Indeks Pembangunan Manusia di Kabupaten/Kota Provinsi Jawa Timur dengan Menggunakan Regresi Panel. Jurnal Sains dan Seni Pmits, 2(2): 237-242.

Mirza, D. S. (2012). Pengaruh Kemiskinan, Pertumbuhan Ekonomi, dan Belanja Modal Terhadap Indeks Pembangunan Manusia di Jawa Tengah Tahun 2006-2009. Economics Development Analysis Journal, 1(1): 1-15.

Muliza, Zulha, T., \& Seftarita, C. (2017). Analisis Pengaruh Belanja Pendidikan, Belanja Kesehatan, Tingkat Kemiskinan, dan PDRB Terhadap IPM di Provinsi Aceh. Jurnal Perspektif Ekonomi Darussalam, 3(1): 51-69.

Mungkasa, O. (2004). Sekilas Kondisi Air Minum dan Sanitasi di Indonesia. Jakarta: Media Percik.

Rizki, B. \& Saleh, S. (2007). Keterkaitan Akses Sanitasi dan Tingkat Kemiskinan: Studi Kasus di Provinsi Jawa Tengah. Jurnal Ekonomi Pembangunan, 12(3): 223-233. https://doi.org/10.20885/ejem.v12i3.378

Samudro, B. R. (2006). The Linkages Between Sanitation and Poverty Level: A Human Development Study in Indonesia. Paper Indonesia Regional Science Association (IRSA), IRSA $8^{\text {th }}$ International Conference Malang,

Sapkota, J. B. (2014). Access to Infrastructure and Human Development: Cross-Country Evidence. JICA Research Institute, 70: 1-26. http://doi.org/10.18884/00000673

Siahaan, S. (2018). Analisis Pengaruh Sanitasi dan angka Kematian Ibu Terhadap Pembangunan Manusia di Sumatra Utara.
Soeranto, D. A. (2004). Kualitas Manusia Indonesia dan Pembangunan Prasarana Sanitasi. Jakarta: Media Percik

Tamboto, H. J. D. \& Manongko, A. A. C. (2019). Model Pengentasan Kemiskinan Masyarakat Pesisir Berbasis Literasi Ekonomi dan Modal Sosial. Jawa Timur: Makaria Waya.

Todaro, M. P. (2003). Pembangunan Ekonomi Dunia Ketiga, Alih Bahasa: Burhanudin Abdullah dan Harris Munandar, Jakarta: Erlangga.

Todaro, M. P \& Smith, S. SC. (2006). Pembangunan Ekonomi Edisi Sembilan Jilid 1. Jakarta: Erlangga.

Umiyati, E., Amril, A., \& Zulfanetti, Z. (2017). Pengaruh Belanja Modal, Pertumbuhan Ekonomi, dan Jumlah Penduduk Miskin Terhadap Indeks Pembangunan Manusia di Kabupaten/Kota Provinsi Jambi. Jurnal Sains Sosiohumaniora, 1(1): 29-37.

UNICEF Indonesia. 2012. Air Bersih, Sanitasi dan Kebersihan. Ringkasan Kajian.

World Health Organization. 2009. Global health risks: Mortality and burden of disease attributable to selected major risks. Geneva: WHO Press. 